\title{
Feed type for induced molting of commercial layer hens
}

\author{
Graciene Conceição dos Santos ${ }^{1}$, Edivaldo Antônio Garcia², Javer Alves Vieira Filho', Andréa \\ de Britto Molino ${ }^{1}$, Kleber Pelícia ${ }^{3}$, Daniella Aparecida Berto ${ }^{1}$, Elise Saori Floriano Murakami ${ }^{4}$, \\ Andressa Takahara Montenegro ${ }^{4}$
}

\footnotetext{
${ }^{1}$ Programa de Pós-Graduação em Zootecnia, Universidade Estadual Paulista "Júlio de Mesquita Filho", Botucatu, SP, Brasil.

2 Departamento de Zootecnia, Universidade Estadual Paulista "Júlio de Mesquita Filho", Botucatu, SP, Brasil.

${ }^{3}$ Departamento de Zootecnia, Universidade José do Rosário Vellano, Alfenas, MG, Brasil.

${ }^{4}$ Curso de Zootecnia, Universidade Estadual Paulista “Júlio de Mesquita Filho", Botucatu, SP, Brasil.
}

\begin{abstract}
An experiment employing three hundred and twenty 81-week-old Lohmann LSL commercial-breed hens was conducted to compare alternative induced-molting methods with the conventional method (fasting). Induced molting lasted 28 days at most, production and quality being monitored for four periods of 28 days thereafter. A completely randomized experimental design with five treatments, eight replicates of eight birds each per plot was adopted. The following experimental treatments were applied until a loss of $26 \%$ of body weight was reached: T1 - fasting, T2 - wheat bran ad libitum, T3 - rice bran ad libitum, T4 - cracked rice ad libitum, T5 - ground alfalfa ad libitum. Birds were then fed production diet ad libitum, except for those on treatment T1 (fasting) which received 30, 60 and $100 \mathrm{~g} / \mathrm{bird} /$ day and then feed ad libitum. During induced molting the birds were exposed to a natural photoperiod and at day 28 that period was increased by 30 minutes/week until reaching 16 hours of light/day. The characteristics evaluated during induced molting were: feed intake, body weight changes and laying percentage. In the post-molt period, performance (feed intake, laying percentage, egg weight, egg mass, feed conversion ratio per dozen and per egg mass and percentage of broken eggs) and egg quality (specific gravity, eggshell breaking strength, percentages of eggshell, yolk, and albumen, eggshell thickness, yolk color and Haugh unit) were evaluated. Every 28 days one egg was collected from each repetition for three consecutive days for quality assessment. The use of rice bran and wheat bran is viable as molting inducers since the birds given those treatments display performance and egg quality similar to those fasted during the induced molting and also because these ingredients promote easier handling, eliminates the need for grinding and feed-mixing equipment and, being less aggressive, provide greater bird welfare.
\end{abstract}

Key Words: cracked rice, egg production, ground alfalfa, rice bran, wheat bran

\section{Introduction}

Molting is a natural process that occurs in all birds and in domestic birds it follows a long production period, lasting approximatley four months. However, through a process known as "productive rest program" which should last no more than 6-8 weeks (Garcia et al., 2001), it is possible to accelerate molt induction to hasten the shedding of feathers and the consequential growth of a new plumage, thus leading to a quicker resumption of egg production.

Mainly because of its simplicity, low cost and satisfactory post-molt results, the most popular molt induction technique is to totally restrict feed in order to force the loss of body weight (Brake, 1993). However, this technique is being challenged because it severely stresses birds, violating good welfare practices. To be accepted by the poultry industry, a method should produce the necessary stimulus to induce changes, ensuring sufficient regression of the reproductive system as well as a post-molt production levels and egg quality similar to those obtained from fasting (Landers et al., 2005).

Since alternative methods of molt induction without total feed restriction might better bird welfare while maintaining satisfactory egg production and quality, they are in the foreground of the current egg industry scenario.

The use of high fiber diets and/or diets with inclusion of anti-nutritional, molt-inducer ingredients has been researched as an alternative to fasting. Among these ingredients are afalfa, with its high protein and fiber levels and low birddigestive-tract passage rates, and saponin, which can suppress feed intake and bird growth (Garcia et al., 2000).

Given the widespread criticism of fasting or severe feed-restriction molt induction methods, and taking into account the importance of the welfare and of the increase in the productive cycle of the birds, the objective of this study was to evaluate alternative methods to induce molt in laying hens and its respective effects on production and egg quality. 


\section{Material and Methods}

This study employed 320 Lohmann LSL commercialbreed laying hens with 81 weeks of age at the beginning of the experiment which were distributed in a completely randomized block design with five treatments and eight replicates of eight birds per plot. The experimental period lasted 140 days, including 28 days for induced molting plus four additional productive cycles of 28 days each.

The birds were housed in a poultry farm equipped with 84 metal cages. The experiment used 40 cages, each $100 \mathrm{~cm}$ long, $40 \mathrm{~cm}$ high and $45 \mathrm{~cm}$ deep, with two compartments each and holding up to four birds per compartment or a total of eight birds per cage. Independent trough feeders placed in front of the cages and nipple water drinkers were also used.

The following experimental treatments were applied until a $26 \%$ loss of body weight was reached: $\mathrm{T} 1$ - fasting, T2 - wheat bran ad libitum, T3 - rice bran ad libitum, T4 cracked rice ad libitum, and T5 - ground alfalfa ad libitum.

During the induced-molting period (28 days), all birds were exposed to a natural photoperiod and received experimental diets according to the designated treatment. After losing $26 \%$ of their body weight, the birds were fed production diet restricted to 30,60 and $90 \mathrm{~g}$ per bird/day for three consecutive days. From the fourth day onwards, production diet was given ad libitum. After the induced molting, the birds were fed production diet and water ad libitum and a lighting program of 14 hours of light per day began with weekly increments of $30 \mathrm{~min}$ to reach a daily photoperiod of 16 hours of light.

During the first 28 days, the birds were weighed on days $0,3,7,10,14,17,21$ and 28 to evaluate changes in body weight. For each treatment, egg production and mortality were controlled daily while feed intake and egg weight were assessed weekly.

The characteristics evaluated during induced molting were feed intake, body weight change and laying percentage. In the post-molt period, bird performance (feed intake, laying percentage, egg weight, egg mass, feed conversion ratio per dozen and per egg mass and percentage of broken eggs) and egg quality (specific gravity, eggshell breaking strength, percentages of eggshell, yolk, and albumen, eggshell thickness, yolk color and Haugh unit) were measured.

Egg quality was verified by collecting one egg from each replicate for three consecutive days every 28 days.

Data variance was analyzed with the help of the computational package Sisvar (Ferreira, 2000). Means were compared by Tukey's test $(\mathrm{P}<0.05)$.

\section{Results and Discussion}

Treatments had no significant effects on the weight of birds on days $0,3,10$ and 28 of the induced-molting period. However, by the third day of induced molting, birds in all treatments had lost about $15 \%$ of their body weight (Table 1).

A significant effect of treatments was observed on bird weight on the seventh day when birds fed ground alfalfa had a lower weight compared with those given rice bran, which showed the greatest weight. The birds on the other treatments had intermediate weights and did not differ significantly. By that time, birds given the ground alfalfa treatment had already reached a weight loss of $27.21 \%$ and began receiving production diet. This loss was greater than that presented by birds on the fasting treatment $(24.62 \%)$. This greater loss can possibly be due to low ground alfalfa intake $(1.87 \mathrm{~g} / \mathrm{bird} /$ day $)$, a fact that can be attributed to several factors, including its low palatability and the presence of saponin, which may have given rise to a reduction in feed intake.

These results differ from those found by Molino (2009), who observed a $21.19 \%$ weight loss on the seventh day of fasting; Scherer et al. (2009), who observed a loss of $20.63 \%$ in birds that underwent fasting for a similar time interval; and Davis et al. (2002), who obtained weight losses of $21.40 \%$ in fasting birds on the 8th day. These weight loss differences may have occurred because of temperature variations and the different choice of breeds in those studies.

Table 1 - Body weight of birds given the experimental treatments during the 28 days of induced molting

\begin{tabular}{|c|c|c|c|c|c|c|c|}
\hline \multirow{2}{*}{ Treatment } & \multicolumn{7}{|c|}{ Days } \\
\hline & 0 & 7 & 10 & 14 & 17 & 21 & 28 \\
\hline Fasting & 1759 & $1326 \mathrm{AB}$ & $1291 *$ & $1477 \mathrm{~A}$ & $1546 \mathrm{~A}$ & $1545 \mathrm{~A}$ & 1605 \\
\hline Rice bran & 1799 & 1417A & 1395 & $1353 \mathrm{AB}$ & $1330 * \mathrm{~B}$ & $1417 \mathrm{ABC}$ & 1582 \\
\hline Cracked rice & 1765 & $1392 \mathrm{AB}$ & 1376 & 1332B & $1297 * \mathrm{~B}$ & 1385BC & 1538 \\
\hline Ground alfalfa & 1742 & $1268 * \mathrm{~B}$ & 1328 & $1471 \mathrm{AB}$ & $1541 \mathrm{~A}$ & $1532 \mathrm{AB}$ & 1573 \\
\hline $\mathrm{CV}(\%)$ & 1.92 & 4.71 & 5.04 & 4.75 & 4.83 & 4.86 & 3.77 \\
\hline
\end{tabular}

Means followed by different letters in the same column differ significantly by Tukey's test $(\mathrm{P}<0.05)$.

* Resumption of production diet ad libitum. 
Although no significant difference in weight could be seen on the 10th day of induced molting, the experimental birds had by then lost on average $23.3 \%$ of their body weights. However, birds on the fasting treatment had mean weight losses of $26.6 \%$ and began being fed production diet ad libitum.

On day 14 , those birds previously undergoing fasting (and from the 10th day fed ad libitum) were heavier than the hens given the cracked rice treatment, while the birds given the other treatments had intermediate weights that did not differ significantly. It should be observed that the birds given the wheat bran, rice bran and cracked rice treatments had by that time lost $22.90,24.79$ and $24.53 \%$ of their body weights. Dalanezi (2007) obtained a weight loss of 20.00\% at 14 days from the onset of induced molting in birds fed wheat bran ad libitum.

At day 17, birds given the alfalfa hay and fasting treatments, which were already receiving production diet ad libitum since the 7th and 10th days, respectively, showed significantly higher weights than those of other treatments, which did not differ.

Also on the 17th day, the birds given the rice bran and cracked rice treatments had lost $26.07 \%$ and $26.51 \%$ of their weights respectively and began to be fed production diet. Similar weight losses were observed by Molino (2009), who found losses of $27 \%$ in birds fed $15 \mathrm{~g}$ feed/bird/day for 14 days, and Dalanezi (2007), who obtained a loss of $26.2 \%$ in birds fed $50 \mathrm{~g}$ wheat bran/bird/day at 21 days after the onset of the induced-molting period.

On day 21, birds given the fasting treatment showed greater weight than those given the wheat bran treatment, while the others showed intermediate weights and did not differ. At that time, the birds of the wheat bran treatment reached a $27.38 \%$ weight loss and began to be fed production diet. Lower results were found by Dalanezi (2007), who observed a loss of $21.9 \%$ when the birds were fed wheat bran ad libitum during a similar time interval.

Treatments had significant effects in all periods analyzed (Table 2). On the first week, birds fed ground alfalfa showed much lower intakes than those on the other treatments. The consumption of ground alfalfa in the first week was $1.87 \mathrm{~g} / \mathrm{bird} /$ day, similar to that found by Sgavioli et al. (2013), who reported intake of $1.63 \mathrm{~g} / \mathrm{bird} /$ day when working with a diet containing $90 \%$ ground alfalfa. That low intake level can be explained by the fact that inclusion of dietary fiber depresses feed intake in hens. This is especially true for alfalfa fibers, which have a slower rate of passage as compared with several other foods, leaving the birds with a sensation of satiety and thus decreasing feed intake. Furthermore, alfalfa has saponins and tannins, which are anti-nutritional components affecting enzyme activity, so it reduces the palatability of the food.

On the second week, feed intake was greatest in birds given wheat bran and ground alfalfa. Such higher intake in birds fed ground alfalfa was expected because they began being fed production diet ad libitum on the seventh day of the induced-molting period. Feed intake was the least in birds fed rice bran, broken rice and in fasting birds, noting that the latter started to receive feed ad libitum on the 10th experimental day. This agrees with Bonato et al. (2004), who, studying feeds with increasing levels of rice bran, observed the occurrence of a decrease in feed intake when birds were fed levels of rice bran addition above $30 \%$. Similar results were found by Santos et al. (2004), who observed that as level of inclusion of rice bran in the diet was increased, the feed intake and body weight of birds decreased. Those authors explain that the reduction in bird performance is due to the presence of $\beta$-glucans, pentosans and non-starch polysaccharides. These substances are not digested by birds but become soluble during the digestion process producing an increase in viscosity of intestinal digesta. By its turn, an increased intestinal digesta viscosity decreases the rate of passage of food through the digestive tract. As a result, the bird eats less food, the action of endogenous enzymes becomes harder and the diffusion or transport of nutrients is disturbed.

In the third week, the highest feed intake was found in birds fasting and those given the ground-alfalfa treatment, followed by the wheat bran and rice bran treatments, which did not differ among themselves, while the lowest intake was observed in birds that received cracked rice. Birds on the rice bran and cracked rice treatments received production diet from the 17th day of the induced-molting period.

While the other treatments did not differ among themselves, the lowest feed intake in the fourth week was observed for birds of the wheat bran treatment, which was expected since those birds only began to receive production diet 21 days after the beginning of the induced-molting period.

Table 2 - Weekly means of average intake per bird per day $(\mathrm{g})$ in the induced-molting rest period

\begin{tabular}{lcccc}
\hline Treatment & Week 1 & Week 2 & Week 3 & Week 4 \\
\hline Fasting & 0B & $51.83 \mathrm{~B}$ & $88.70 \mathrm{~A}$ & $101.25 \mathrm{~A}$ \\
Wheat bran & $34.15 \mathrm{~A}$ & $75.16 \mathrm{~A}$ & $69.70 \mathrm{~B}$ & $84.67 \mathrm{~B}$ \\
Rice bran & $27.85 \mathrm{~A}$ & $51.08 \mathrm{~B}$ & $76.51 \mathrm{~B}$ & $99.16 \mathrm{~A}$ \\
Cracked rice & $22.21 \mathrm{~A}$ & $48.10 \mathrm{~B}$ & $53.87 \mathrm{C}$ & $95.46 \mathrm{~A}$ \\
Ground alfalfa & $1.87 \mathrm{~B}$ & $65.67 \mathrm{~A}$ & $90.02 \mathrm{~A}$ & $99.67 \mathrm{~A}$ \\
CV $(\%)$ & 51.76 & 13.35 & 6.96 & 5.29 \\
\hline
\end{tabular}

Means followed by different letters in the same column differ significantly by Tukey's test $(\mathrm{P}<0.05)$. 
There were no significant differences in laying percentages among treated birds on the onset of the experiment and on the 7th and 10th days of the inducedmolting period (Table 3). Also, birds given the wheat bran, cracked rice and ground alfalfa treatments stopped laying on the 7th day, while those fasting and fed wheat bran showed values close to zero and stopped laying within 10 days. Different results were reported by Davis et al. (2002), who observed that birds undergoing fasting and those given a diet with $50 \%$ cottonseed meal interrupted laying on the 5th day. Keshavarz and Quimby (2002) reported that chickens subjected to total feed restriction and to a diet of grape residue with addition of $10 \mathrm{ppm}$ thyroxine stopped laying respectively on the third and fourth days. Sgavioli et al. (2013) observed that birds given diets containing 90\%, $70 \%$ and $50 \%$ of ground alfalfa or diet with the addition of $2800 \mathrm{ppm}$ zinc or under feed restriction ceased laying in $3.67,3.67,4.22,3.89$ and 3.44 days respectively. Koelkebeck and Anderson (2007) mention that during fasting, domestic fowls tend to use all nutrients for body maintenance and do not divert them for production.

By 21 days, the birds in the ground alfalfa and fasting treatments had resumed laying, which probably happened because the birds given those treatments began to be fed production diet at 7 and 10 days, respectively.

Starting to receive production diet only at 21 days of the induced-molting period, only the birds given wheat bran treatment had not resumed laying by 28 days. During that period, birds fasting and given ground alfalfa showed higher egg production when compared with those fed cracked rice and rice bran.

Table 3 - Percentage of egg production for each experimental treatment during the induced-molting period

\begin{tabular}{lccccc}
\hline Treatment & 1 & 7 & 10 & 21 & 28 \\
\hline Fasting & 71.87 & 1.56 & 0.00 & $19.29 \mathrm{~B}$ & $42.86 \mathrm{~A}$ \\
Wheat bran & 73.44 & 0.00 & 0.00 & $0.00 \mathrm{C}$ & $0.00 \mathrm{C}$ \\
Rice bran & 70.31 & 3.12 & 0.00 & $0.00 \mathrm{C}$ & $8.04 \mathrm{BC}$ \\
Cracked rice & 75.00 & 0.00 & 0.00 & $0.00 \mathrm{C}$ & $20.76 \mathrm{~B}$ \\
Ground alfalfa & 67.19 & 0.00 & 0.00 & $33.48 \mathrm{~A}$ & $48.00 \mathrm{~A}$ \\
CV $(\%)$ & 11.10 & 34.73 & 0.00 & 76.93 & 58.31 \\
\hline
\end{tabular}

Means followed by different letters in the same column differ significantly by Tukey's test $(\mathrm{P}<0.05)$.
There was no significant difference among experimental treatments in the post-molt period for feed intake, laying percentage, breaking percentage and egg mass (Table 4). Scherer et al. (2009) found differences in laying percentage, feed intake and egg mass, in which birds fasting showed greater laying percentage, feed intake and egg mass compared with birds treated with production diet with restriction of calcium and phosphorus, production diet with restriction of calcium, phosphorus and sodium, and production diet with restriction of calcium, phosphorus, sodium, methionine and lysine, and ground corn.

Significant differences were observed in egg weight and in feed conversion per $\mathrm{kg}$ or per dozen eggs, in which the highest egg weight was observed in birds undergoing fasting compared with the cracked rice treatment; the other treatments not differing. These results are in agreement with Oliveira (1994), who observed that birds fasting during induced molting showed greater egg weights than those fed low-energy diet either ad libitum or restricted to $45 \mathrm{~g} / \mathrm{bird} /$ day for 27 days, as well as with Molino et al. (2009), who found the highest egg weights in birds fasting or under a restriction of $15 \mathrm{~g} / \mathrm{bird} /$ day compared with those under restriction of 30,45 or $60 \mathrm{~g} / \mathrm{bird} /$ day.

The best feed conversions were observed in birds fed ground alfalfa in the induced-molting period compared with those fed cracked rice, and did not differ from the other treatments.

Studying the use of low-density diets restricted to $45 \mathrm{~g} / \mathrm{bird} /$ day for 27 days to induce molting as compared with the conventional method, Ramos et al. (1999) observed better feed conversion per $\mathrm{kg}$ in fasting birds.

Magalhães et al. (2010) observed greater feed conversion per $\mathrm{kg}$ in birds fasting for 11 days and birds fed $40 \%$ detoxified castor bean meal ad libitum until losing $23 \%$ of body weight, compared with birds fed 20 and $30 \%$ detoxified castor bean meal ad libitum until losing $23 \%$ of body weight.

There were no significant differences in egg specific gravity, eggshell thickness, percentages of yolk, albumen and eggshell, Haugh unit or yolk color in the post-molt period (Table 5). Girardon (2011) found differences for

Table 4 - Effect of the different treatments in the molting period on the performance of birds during the post-molting period

\begin{tabular}{|c|c|c|c|c|c|c|c|}
\hline Treatment & FI (g) & EW (g) & LP (\%) & BRK (\%) & EM (g) & $\mathrm{FC} / \mathrm{kg}$ & $\mathrm{FC} / \mathrm{dz}$ \\
\hline Fasting & 118.48 & $71.96 \mathrm{~A}$ & 79.72 & 0.57 & 57.33 & $2.50 \mathrm{AB}$ & $1.87 \mathrm{AB}$ \\
\hline Wheat bran & 117.81 & $69.81 \mathrm{AB}$ & 81.78 & 0.28 & 57.31 & $2.50 \mathrm{AB}$ & $2.05 \mathrm{AB}$ \\
\hline Rice bran & 119.86 & $70.15 \mathrm{AB}$ & 82.65 & 0.54 & 58.09 & $2.23 \mathrm{AB}$ & $1.87 \mathrm{AB}$ \\
\hline Cracked rice & 116.34 & $69.65 \mathrm{~B}$ & 78.34 & 0.52 & 54.63 & $2.53 \mathrm{~A}$ & $2.09 \mathrm{~A}$ \\
\hline Ground alfalfa & 116.14 & $70.49 \mathrm{AB}$ & 81.12 & 0.38 & 57.12 & $2.12 \mathrm{~B}$ & $1.78 \mathrm{~B}$ \\
\hline $\mathrm{CV}(\%)$ & 2.47 & 2.23 & 4.78 & 78.60 & 4.97 & 11.91 & 10.60 \\
\hline
\end{tabular}

FI - feed intake; EW - egg weight; LP - egg-laying percentage; BRK - broken eggs; EM - egg mass; FC/kg - feed conversion per kg; FC/dz - feed conversion per dozen eggs. Means followed by different letters in the same column differ significantly by Tukey's test $(\mathrm{P}<0.05)$. 
Table 5 - Effect of the different treatments in the molting-period on the egg quality of birds during the post-molting period

\begin{tabular}{lcccccccc}
\hline Treatment & $\mathrm{SG}\left(\mathrm{mg} / \mathrm{cm}^{3}\right)$ & BRK $(\mathrm{kgf})$ & THK $(\mathrm{mm})$ & YLK $(\%)$ & ALB $(\%)$ & SHL $(\%)$ & UH & CLR \\
\hline Fasting & 1.079 & $3566 \mathrm{~B}$ & 0.35 & 24.76 & 65.35 & 8.18 & 90.18 & 6.63 \\
Wheat bran & 1.082 & $3881 \mathrm{~A}$ & 0.36 & 24.73 & 66.77 & 8.50 & 89.41 \\
Rice bran & 1.080 & $3673 \mathrm{AB}$ & 0.36 & 24.91 & 66.58 & 8.51 & 88.94 \\
Cracked rice & 1.081 & $3868 \mathrm{AB}$ & 0.36 & 24.18 & 66.66 & 8.51 & 86.46 & 6.50 \\
Ground alfalfa & 1.080 & $3642 \mathrm{AB}$ & 0.35 & 24.92 & 66.78 & 8.29 & 89.41 & 6.62 \\
CV $(\%)$ & 0.20 & 5.71 & 3.49 & 4.80 & 3.44 & 3.56 & 3.16 & 7.52 \\
\hline
\end{tabular}

Means followed by different letters in the same column differ significantly by Tukey's test $(\mathrm{P}<0.05)$.

SG - specific gravity; BRK - breaking strength; THK - eggshell thickness; YLK - percentage of yolk; ALB - percentage of albumen; SHL - percentage of eggshell; HU - Haugh unit; CLR - yolk color.

Haugh unit and shell thickness using feed restriction for 10 days, soybean hull ad libitum for 14 days, wheat bran and vitamin-mineral premix for 14 days and high-tannin sorghum and premix mineral-vitamin for 14 days, in which birds fed soybean hull showed the best results for Haugh unit and shell thickness.

There were significant differences in eggshell breakage strength, in which the eggs from birds fed the wheat bran treatment were stronger compared with the eggs from fasting birds, but did not differ from the other treatments. This was probably a consequence of the longer resting period of the reproductive tract of birds fed wheat bran, which were kept out of production longer than the fasting birds. This might have led to a better recovery of bodycalcium and phosphorus reserves. Molino et al. (2009) found the best results for eggshell breaking strength in birds fed 15, 45 and $60 \mathrm{~g} / \mathrm{bird} /$ day compared with fasting birds and birds fed $30 \mathrm{~g} / \mathrm{bird} /$ day during the induction of molt.

\section{Conclusions}

The use of rice bran and wheat bran is feasible for inducing molt because they are low-cost, easily applicable methods, and because birds cease production of eggs, lose weight and show post-molt performance and egg quality similar to the fasting method, having better welfare.

\section{References}

Bonato, E. L.; Zanella, I.; Santos, R.; Gasparini, S. P.; Magon, L.; Pires, A. R. and Brittes, L. P. 2004. Uso de enzimas em dietas contendo níveis crescentes de farelo de arroz integral para frangos de corte, Ciência Rural 34:511-516.

Brake, J. 1993. Recent advances in induced molting. Poultry Science 72:929-931.

Davis, A. J.; Lordelo, M. M. and Dale, N. 2002. Use of cottonseed meats in molting programs. Journal of Applied Poultry Research 11:175-178.

Dalanezi, J. A. 2007. Produção e qualidade dos ovos de poedeiras comerciais semipesadas submetidas a programas de muda forçada. Tese (D.Sc.). Faculdade de Medicina Veterinária e Zootecnia, Universidade Estadual Paulista, Botucatu.
Ferreira, D. F. 2000. Sistema de análises de variância para dados balanceados. UFLA, Lavras. (SISVAR 4. 1. pacote computacional).

Garcia, J.; Carabanõ, R.; Peréz-Alba, L. and Blas, J. C. 2000. Effect of fiber source on cecal fermentation and nitrogen recycled through cecotrophy in rabbits. Journal Animal Science 78:638-646.

Garcia, E. A; Mendes, A. A; Pizzolante, C. C and Veiga, N. 2001. Alterações morfólogicas de codornas poedeiras submetidas a muda forçada. Revista Brasileira de Ciência Avícola 3:265-273.

Girardon, J. C. 2011. Métodos nutricionais de muda forçada em poedeiras semi-pesadas. Dissertação (M.Sc.). Universidade Federal de Pelotas, Pelotas.

Keshavarz, K. and Quimby, F. W. 2002. An investigation of different molting techiniques with an emphasis on animal welfare. Journal Applied Poultry Research 11:54-67.

Koelkebeck, K. W. and Anderson, K. E. 2007. Molting layers Alternative methods and their effectiveness. Poultry Science $86: 1260-1264$

Landers, K. L.; Woodward, C. L.; Li, X.; Kubena, L. F.; Nisbet, D. J. and Ricke, S. C. 2005. Alfalfa as a single dietary source for molt induction in laying hens. Bioresource Technology 96:565-570.

Magalhães, K. S.; Freitas, E. R. and Cruz, C. E. B. 2010. Desempenho de poedeiras submetidas a muda forçada com rações contendo torta de mamona não destoxificada. In: Anais da 47a Reunião Anual da Sociedade Brasileira de Zootecnia. Sociedade Brasileira de Zootecnia, Salvador.

Molino, A. B.; Garcia, E. A.; Berto, D. A.; Pelicia, K; Silva, A. P. and Vercese, F. 2009. The effects of alternative forced-molting methods on the performance and egg quality of commercial layers. Revista Brasileira de Ciência Avícola 11:109-113.

Oliveira, R. M. 1994. Avaliação comparativa de alguns métodos de indução de muda em poedeiras comerciais. Dissertação (M.Sc.). Escola Superior de Agricultura de Lavras, Lavras.

Ramos, R. B.; Fuentes, M. F. F.; Espíndola, G. B; Lima, F. A. M. and Freitas, E.R. 1999. Efeitos de diferentes métodos de muda forçada sobre o desempenho de poedeiras comerciais. Revista Brasileira de Zootecnia 28:1340-46.

Santos, R.; Zanella, I; Bonato, E. L.; Rosa, A. P.; Magon, L.; Gasparini, S. P. and Brittes, L. B. P. 2004. Diminuição dos níveis de cálcio e fósforo em dietas com farelo de arroz integral e enzimas sobre o desempenho de frangos de corte. Ciência Rural 34:517-521.

Scherer, M. R.; Garcia, E. A.; Berto, D. A.; Molino, A. B.; Faitarone, A. B. G., Pelicia, K.; Silva, A. P. S. and Móri, C. 2009. Efeito dos métodos de muda forçada sobre o desempenho e qualidade dos ovos de poedeiras comerciais durante o segundo ciclo produtivo. Veterinária e Zootecnia 16:195-203.

Sgavioli, S.; Filardi, R. S.; Praes, M. F. F. M.; Domingues, C. H. F.; Andrade, P. C.; Boleli, I. C. and Junqueira, O. M. 2013. Effect of forced-molting methods and rearing temperatures on the performance and organ biometrics of laying hens. Revista Brasileira de Ciência Avícola 15:239-245. 